\title{
Variable modes of facilitation in the upper intertidal: goose barnacles and mussels
}

\author{
Takashi Kawai*, Mutsunori Tokeshi \\ Amakusa Marine Biological Laboratory, Kyushu University, Tomioka 2231, Reihoku-Amakusa, Kumamoto 863-2507, Japan
}

\begin{abstract}
Two sessile filter-feeders of similar body sizes, the goose barnacle Capitulum mitella and mussel Septifer virgatus, occur in patches on a moderately wave-exposed rocky shore of south Japan in the western Pacific. Their pattern of coexistence was investigated through field observations and experimental manipulation, focusing in particular on seasonally variable modes of facilitation under harsh environmental conditions found in the upper intertidal. Field observations and reciprocalremoval experiments showed a high survivorship of C. mitella in both mixed patches (containing C. mitella and $S$. virgatus) and Capitulum-only patches. In contrast, $S$. virgatus exhibited a substantially higher survivorship in the mixed than in single situations, indicating that $S$. virgatus was positively affected by the presence of $C$. mitella, while the latter was not influenced by the presence of the former in the upper intertidal. An artificial patch transplant experiment demonstrated that $C$. mitella enhanced $S$. virgatus survivorship and growth both in summer when thermal stress was severe and in winter when physical disturbance caused by wave action was strong. In contrast, the artificial shade treatment enhanced $S$. virgatus survivorship only in summer. In summer, thermal conditions (temperature and interstitial humidity within patches) were harsher in the unshaded ( $S$. virgatus-only) than in the mixed (C. mitella $+S$. virgatus) and shaded treatments ( $S$. virgatus with artificial shade). In contrast, the effect of severe physical condition as evidenced by the extent of shell wear in mussels was more pronounced in the shaded and unshaded treatments than in the mixed treatment in winter. These results suggest that $C$. mitella had 2 different habitat-modifying functions: (1) amelioration of thermal stress and (2) amelioration of physical stress; the artificial shade performed only the first of these.
\end{abstract}

KEY WORDS: Facilitation - Temporal variability · Habitat amelioration - Thermal stress · Physical disturbance $\cdot$ Goose barnacles $\cdot$ Mussels

Resale or republication not permitted without written consent of the publisher

\section{INTRODUCTION}

Clarifying mechanisms of species coexistence is one of the main themes of community ecology (Tokeshi 1999). Niche differentiation (Schoener 1974, Tilman 1982) and predator- or disturbance-mediation (Paine 1966, Connell 1978) including, in particular, indirect interactions (Strauss 1991, Miller 1994, Schoener 1994, Wootton 1994a,b, Menge 1995, Abrams et al. 1996) have been studied intensively. All these processes concern the mediation of negative elements of species interaction. At the same time, the commonness and importance of positive interactions in species coexis- tence have been increasingly recognised with critical evaluation in a wide range of natural communities in both marine and terrestrial habitats (Bertness \& Callaway 1994, Callaway 1995, Bruno et al. 2003). In marine systems, mussels (Suchanek 1985, Witman 1987, Tokeshi \& Romero 1995), seaweeds (Dayton 1975, Menge 1978a,b, Thompson et al. 1996, Bertness et al. 1999) and seagrasses (Heck \& Orth 1980, Stoner \& Lewis 1985, Irlandi \& Peterson 1991) have been frequently identified as habitat-modifying organisms that can influence the success of associated organisms by modifying physically and/or biologically stressful conditions (e.g. thermal stress: Dayton 1975, Hawkins 
1981, Bertness et al. 1999, Leonard 1999; low nutrient levels: Williams 1990; disturbance: Bertness \& Grosholz 1985; predation: Heck \& Orth 1980, Witman 1987). In terrestrial habitats, many plants can facilitate other plants by ameliorating physical stresses (Nobel 1984, Callaway 1992), altering substrate characteristics (Callaway et al. 1991), increasing resource availability (Walker \& Vitousek 1991, Chapin et al. 1994), or providing protection from herbivores (Hjältén et al. 1993).

In these cases of positive interaction, the size scales of interacting species are generally very different: the facilitator is often substantially larger than the facilitated. In fact, few studies have demonstrated positive interactions between similar-sized species (e.g. Navarrete \& Castilla 1990, Bertness \& Yeh 1994). Furthermore, even in those rare cases, coexistence is generally transient and cannot persist as succession proceeds (cf. the facilitation model: Connell \& Slatyer 1977). Therefore, a fundamental question arises as to whether there are cases in which the coexistence of potentially competing, similarsized species is facilitated by the positive effect of one species on another in a non-transient manner.

Generally, environmental stress factors and their magnitudes show spatial and temporal variation. It has been suggested that the nature of interactions may shift from positive, under environmentally stressful conditions, to neutral, and eventually become negative with decreasing stresses (Bertness \& Callaway 1994, Callaway \& Walker 1997, Brooker \& Callaghan 1998). Indeed, some previous studies have indicated such shifts on different spatial scales (e.g. intertidal assemblages: Bertness et al. 1999; alpine plants: Callaway et al. 2002). On the other hand, few studies have assessed temporal variability in stress factors and the nature of interactions at the same site.

The organisms chosen for the present study, the goose barnacle Capitulum mitella and the mussel Septifer virgatus, occur in the mid- to upper intertidal on temperate to subtropical rocky shores of the western Pacific. The 2 species have broadly overlapping geographical ranges (Mori et al. 1985a,b, Tanaka et al. 1985, Nakamura \& Tanaka 1989), and similar modes of life (sessile, filter feeding) and body sizes. On moderately wave-exposed rocky shores of Amakusa, southern Japan, C. mitella individuals usually form patches of various sizes on rock surfaces and $S$. virgatus individuals often occur within C. mitella patches, thus forming mixed patches (Nakamura \& Tanaka 1995). Our work was stimulated by an observation that $S$. virgatus occurred only within C. mitella patches on flat rock surfaces in the upper intertidal in Amakusa. This suggested that the goose barnacle $C$. mitella might positively influence the survivorship and growth of $S$. virgatus through mitigation of certain factors in the upper intertidal.
The present study aimed to evaluate the pattern of coexistence in Capitulum mitella and Septifer virgatus, with special reference to variable modes of facilitation under seasonally different environmental conditions. In particular, a hypothesis that $C$. mitella can have significant positive effects on the demography of $S$. virgatus through amelioration of seasonally varying thermal stress and physical disturbance was tested by field observations and experimental manipulation.

\section{MATERIALS AND METHODS}

Study site. The study was carried out on a moderately wave-exposed rocky shore of the Shikizaki promontory $\left(32^{\circ} 31^{\prime} \mathrm{N}, 130^{\circ} 02^{\prime} \mathrm{E}\right)$ on the Amakusa Shimoshima Island, western Kyushu, in southern Japan. This region has a subtropical climate, with the surface water temperature ranging from 13 to $29^{\circ} \mathrm{C}$. The study site was on the open coast, where strong waves caused by wind were often observed in winter. The mean tidal difference was $3.3 \mathrm{~m}$ at spring tide, with a mean tide level of $1.9 \mathrm{~m}$ above sea level. The goose barnacle Capitulum mitella generally occurs on both horizontal and vertical rock surfaces from the mid to upper intertidal. C. mitella usually aggregates around crevices and depressions, forming patches of various sizes (1 to $350 \mathrm{~cm}^{2}$ ) often mixed with the mussel Septifer virgatus. The small acorn barnacle Chthamalus challengeri also occurs on horizontal and vertical rock surfaces, while the large acorn barnacle Tetraclita japonica occurs mainly on vertical rock surfaces. Mobile organisms in this community include the herbivorous snail Nodilittorina radiata, the chiton Acanthopleura japonica, the limpet Siphonaria japonica and the predatory snails Morula musiva and Thais clavigera. Field observations and experiments were carried out in the upper intertidal zone (2.0 to $2.5 \mathrm{~m}$ above sea level) between August 2000 and February 2002.

Field observations. Patches of Capitulum mitella and Septifer virgatus were categorised into the following 2 types: (1) mixed patches composed of both $C$. mitella and $S$. virgatus, and (2) Capitulum-only patches. Septifer-only patches were not observed in our study site at any time during the year. To examine the effects of patch types on $C$. mitella and $S$. virgatus survivorship under natural conditions, photographic surveys were conducted in subtropical 'summer' (August 2001 to October 2001) and 'winter' (December 2001 to February 2002). From 15 to 42 natural patches of each type were chosen in the upper intertidal zone and all individuals of the 2 species within each patch were identified. Survivorship was defined as the proportion of the identified individuals that persisted until the end of a 3 mo monitoring period. 
Removal experiment. A removal experiment was conducted to examine interspecific interactions between the goose barnacle Capitulum mitella and mussel Septifer virgatus within the naturally occurring mixed patches between August and December 2000. In August 2000, 36 middle-sized mixed patches (mean area $=44.5 \mathrm{~cm}^{2}$ ) were chosen in the upper intertidal zone and randomly assigned to each of the 3 treatments (12 replicates each): (1) Septifer-removal, (2) Capitulum-removal, and (3) control. Patch sizes did not differ significantly among the treatments (ANOVA: $\left.F_{2,33}=3.13, \mathrm{p}>0.05\right)$. At the beginning of this experiment, all individuals of $S$. virgatus (Treatment 1 ) and C. mitella (Treatment 2) were carefully removed from rock surfaces with a knife. Both goose barnacles and mussels within patches of the control treatment were left untouched. Immediately after removal, these patches were photographed for identification of individuals. After 15, 25, 60 and $100 \mathrm{~d}$ from the start of experimental treatment, these patches were monitored for survivorship of each species. Survivorship was defined as the proportion of the identified individuals that persisted until the following monitoring date.

Transplant experiment. In order to test the hypothesis that the positive effect of Capitulum mitella on Septifer virgatus involves amelioration of seasonally varying thermal stress and physical disturbance, an artificial patch transplant experiment was run twice (August to November 2001 and December 2001 to February 2002). A total of 24 artificial patches were prepared and assigned to 3 treatments (8 replicates each): (1) mixed, (2) Septifer-only without shade, and (3) Septifer-only with shade. Middle-sized C. mitella (10 to $20 \mathrm{~mm}$ in R-T length, see below) and $S$. virgatus (25 to $40 \mathrm{~mm}$ in shell length, see below) were collected from the upper intertidal habitats near the transplant site. Size of each species was defined as the length between the rostrum and the tip of the tergum ('R-T length') in C. mitella and shell length (the maximum anterior-posterior axis) in $S$. virgatus. Individuals were measured with digital callipers to the nearest $0.01 \mathrm{~mm}$ and marked with small numbered tags.

For the mixed patches, 16 Capitulum mitella were glued in a circle onto a $10 \times 10 \times 1 \mathrm{~cm}$ ceramic tile using water-resistant epoxy resin, and 10 Septifer virgatus were placed within the Capitulum-circle and allowed to adjust their positions and attach to the tile and to one another by byssal threads. These tiles were kept in a laboratory running-seawater aquarium for $1 \mathrm{wk}$ to allow firm attachment and acclimatisation. The size of artificial mixed patches (50 to $60 \mathrm{~cm}^{2}$ ) corresponded to natural patches and the proportion of $S$. virgatus within the artificial patch $(\sim 40 \%)$ was adjusted to a relatively high level observed in the upper intertidal zone. For the unshaded and the shaded treatments,
$10 \mathrm{~S}$. virgatus were placed in the centre of a ceramic tile and allowed to attach to the tile in the aquarium for $1 \mathrm{wk}$. After all the mussels had attached firmly, the tiles were taken to the field and randomly placed on rock surfaces using stainless steel screws on a slightly sloping flat rock in the upper intertidal. Each artificial patch was covered with a predator exclusion cage $(10 \times$ $10 \times 5 \mathrm{~cm}$ ) constructed of $5 \times 5 \mathrm{~mm}$ stainless mesh. This excluded predatory snails Morula musiva and Thais clavigera; in the field, the actual density of these predatory snails was very low in summer and virtually nil in winter in the experimental area. The shaded treatment involved coverage by a $10 \times 10 \mathrm{~cm}$ doublelayered canopy of white plastic screen $(0.5 \times 0.5 \mathrm{~mm}$ mesh) attached to the top of the cage to reduce solar radiation. All marked individuals of the 2 species were monitored for survivorship throughout the experiment and measured for growth during the first 6 wk of the experimental period. Growth rate was calculated as relative size increase per day for each individual, using the following formula:

$$
r=\frac{L_{t_{2}}-L_{t_{1}}}{L_{t_{1}}\left(t_{2}-t_{1}\right)} \times 100
$$

where $r$ is the growth rate, $L_{t_{1}}$ and $L_{t_{2}}$ are the shell length at time $t_{1}$ and $t_{2}$, respectively, and $t$ is time in days. At the end of the experiment, shell length of dead mussels was measured and the magnitude of shell wear was estimated by calculating the proportional decrease in shell length of dead mussels from the initial length.

Mussel shell surface temperature, interstitial temperature, humidity within the artificial patches and the amount of water retained on the bottom of a patch were quantified to characterise thermal conditions in the treatments. Shell surface temperature of a living mussel was taken with a radiant thermometer (IT-330, Horiba) placed centrally in each artificial patch. Interstitial temperature and humidity were measured with a thermo-hygrometer (SU-610, Testo) inserted into interstices of mussels. Measurements (5 to 8) of shell surface temperature, interstitial temperature and humidity were taken 1 and $3 \mathrm{~h}$ after all experimental patches were exposed by the receding tide at midday on windless, fine days in September 2001 and January 2002. The amount of water retained in a patch was estimated with $20 \mathrm{~g}$ completely dried silica gel scattered into interstices for $10 \mathrm{~min}$. Water gain was calculated as the difference between the initial and final weight of the silica gel. Five to 8 replicate measurements were taken after $30 \mathrm{~min}$ and $3 \mathrm{~h}$ of low-tide exposure.

Data analysis. A 2-tailed Fisher's exact test was used to assess the survivorship of each species within natural patches. Temporal pattern in the survivorship of the 2 species was evaluated using repeated-measures 
ANOVA. Most other data were analysed with 1-factor ANOVA with experimental treatment as a fixed factor, or 2-factor ANOVA with experimental treatment and season as fixed factors. Where appropriate, Scheffé's test was used for a posteriori multiple comparison of means $(\alpha=0.05$; where the homoscedasticity assumption was violated, the significance level $\alpha$ was set at 0.01). Bartlett's test was used to check the assumption of homogeneity of variances and, where necessary, proportional data were arcsine transformed (Zar 1996) (note, however, that untransformed means were used for graphic presentation).

\section{RESULTS}

\section{Survivorship}

Field observations

In the upper intertidal, mixed and Capitulum-only patches occurred throughout the year, while no Septifer-only patch occurred. The survivorship of C. mitella was very high (over $88 \%$ ) and not significantly
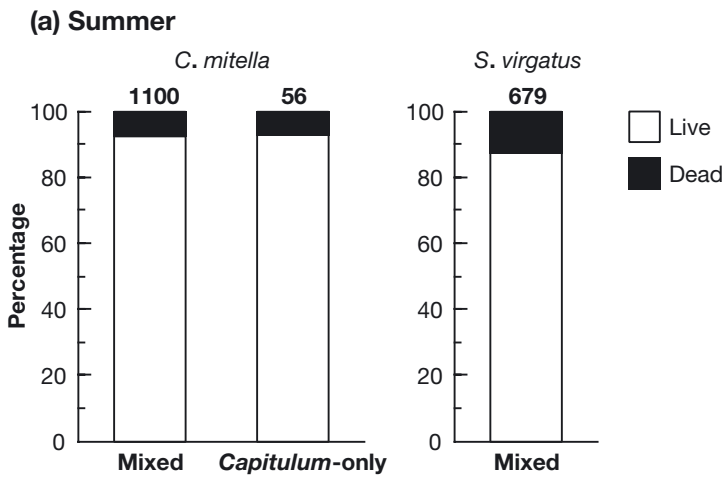

(b) Winter
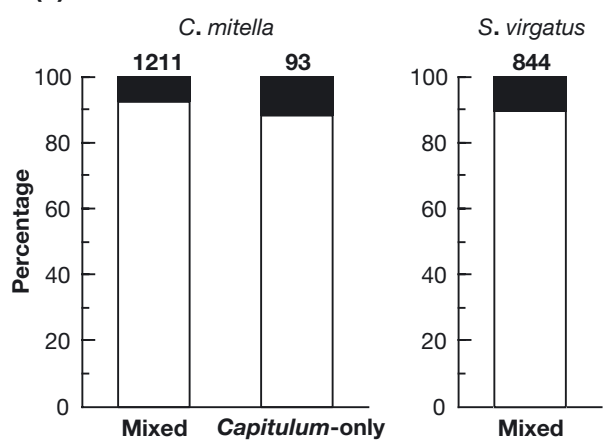

Fig. 1. Capitulum mitella and Septifer virgatus. Proportion of live and dead individuals in different types of patch. (Summer: mixed, $\mathrm{n}=15$; Capitulum-only, $\mathrm{n}=31$. Winter: mixed, $\mathrm{n}=16$; Capitulum-only, $\mathrm{n}=42$.) No Septifer-only patch occurred. Total numbers of individuals are given for each patch type above the bars different between the mixed and the Capitulum-only patches in either summer or winter (2-tailed Fisher's exact test: summer, $\mathrm{p}=0.87$; winter, $\mathrm{p}=0.16$; Fig. 1 ). Mussel survivorship was also high (over $85 \%$ ) in the mixed patches and did not show seasonal variation (2-tailed Fisher's exact test: $\mathrm{p}=0.13$; Fig. 1).

\section{Removal experiment}

The survivorship of Septifer virgatus was positively affected by the presence of Capitulum mitella, while that of $C$. mitella was not influenced by $S$. virgatus in the upper intertidal (Fig. 2). There was no difference in C. mitella survivorship between the control and the Septifer-removal treatments (Fig. 2a, Table 1a). C. mitella survivorship was uniformly high (over 90\%) throughout the experimental period in both treatments. In contrast, the survivorship of $S$. virgatus varied with treatment $\times$ time interaction (Fig. 2b, Table 1b). There was no difference in survivorship between treatments until Day 25 from the start of the experiment. Mussel survivorship suddenly declined, however, in the Capitulum-removal treatment after Day 25. By Day 60, 40\% of mussels in the Capitulumremoval treatment died, and by Day 100 nearly $50 \%$

(a) C. mitella

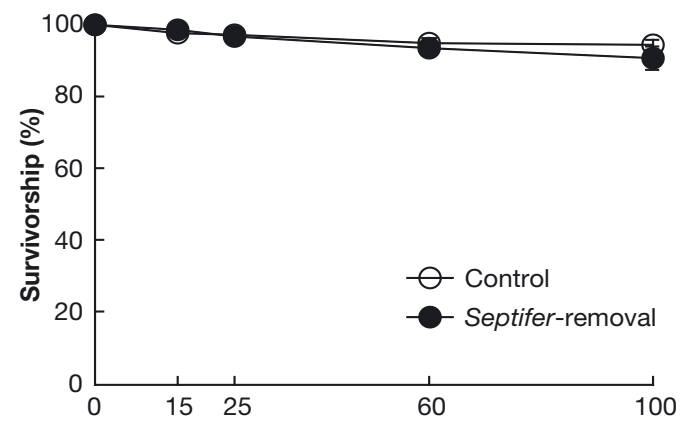

(b) S. virgatus

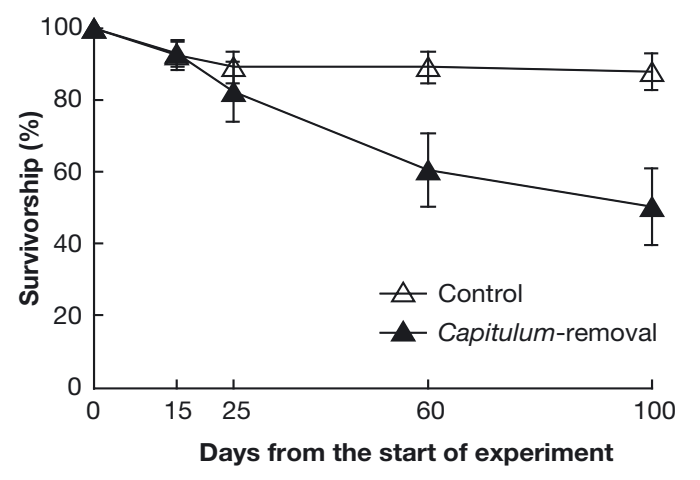

Fig. 2. Capitulum mitella and Septifer virgatus. Survivorship of (a) C. mitella and (b) S. virgatus in removal experiment. Values are untransformed means $\pm 1 \mathrm{SE}$ 
Table 1. Capitulum mitella and Septifer virgatus. Results of 2-factor, repeatedmeasures ANOVA on the survivorship of (a) C. mitella and (b) $S$. virgatus in the removal experiment. Data were arcsine (square root) transformed before analysis. Denominator MS for the $F$ ratios: $\mathrm{b}=$ Subject (group) error, $\mathrm{c}=$ Time $\times$ Subject (group) error

\begin{tabular}{|lrrrrr|}
\hline Source of variation & df & MS & $F$ & MS & p \\
\hline (a) C. mitella & & & & & \\
Treatment & 1 & 32.02 & 0.20 & $\mathrm{~b}$ & 0.658 \\
Subject (group) error & 22 & 158.90 & & & \\
Time & 4 & 646.56 & 24.69 & $\mathrm{C}$ & $<0.001$ \\
Time $\times$ Treatment & 4 & 22.92 & 0.88 & $\mathrm{C}$ & 0.482 \\
Time $\times$ Subject (group) error & 88 & 26.19 & & & \\
Total & 119 & & & & \\
& & & & & \\
(b) $\boldsymbol{S}$. virgatus & & & & & \\
Treatment & 1 & 5089.91 & 5.05 & $\mathrm{~b}$ & 0.035 \\
Subject (group) error & 22 & 1007.73 & & & \\
Time & 4 & 3567.30 & 17.50 & $\mathrm{C}$ & $<0.001$ \\
Time $\times$ Treatment & 4 & 1434.60 & 7.04 & $\mathrm{C}$ & $<0.001$ \\
Time $\times$ Subject (group) error & 88 & 203.80 & & & \\
Total & 119 & & & & \\
\hline
\end{tabular}

cant difference among treatments. During the next $28 \mathrm{~d}$, however, the magnitude of decrease in survivorship varied with treatments, the greatest being in the unshaded treatment, intermediate in the shaded treatment and smallest in the mixed treatment. In the unshaded treatment, nearly $80 \%$ of mussels died by Day 42 and continued to decline towards 0 at the end of the experiment. Mussel survivorship in the shaded treatment also declined rapidly after Day 14, reaching nearly $50 \%$ by Day 42 and $10 \%$ at the end. In contrast, although mussels in the mixed treatment showed a slight decreasing trend from Days 14 to 42, after that period mortality was low. In the end, over $70 \%$ of mussels in the mixed treatment survived through the experimental period. These results died. In contrast, the survivorship of mussels in the control treatment was uniformly high (nearly 90\%) throughout the experimental period.

\section{Transplant experiment}

Almost all individuals of Capitulum mitella in the mixed treatment survived throughout the experimental periods in both seasons (Fig. 3). Mussel survivorship in summer varied with treatment $\times$ time interaction (Fig. 3a, Table 2a). The survivorship of mussels in the unshaded treatment rapidly declined. During the first $2 \mathrm{wk}$ from the start of experiment, $60 \%$ of mussels in the unshaded treatment died. Moreover, by Day 42 nearly $80 \%$ of mussels died, while from Day 42 onwards no mussels died. In contrast, mussel survivorship in the mixed treatment was constantly high (over $80 \%$ ) throughout the experimental period. Mussels in the shaded treatment also showed a high survivorship $(\sim 80 \%)$ during the first half of experimental period, in contrast to those in the unshaded treatment (Scheffé's test: Day 14, $\mathrm{p}=0.013$; Day 28, $\mathrm{p}=0.006$; Day 42, $\mathrm{p}=$ 0.011). However, mussel survivorship in the shaded treatment gradually declined to ca. $50 \%$ and the difference with the unshaded treatment became non-significant towards the end of the experiment (Scheffé's test: Day 84, p = 0.43).

Mussel survivorship in winter also varied with treatment $\times$ time interaction, though the pattern was slightly different from summer (Fig. 3b, Table 2b). During the first $14 \mathrm{~d}$, only a few mussels (less than $10 \%$ ) died in all treatments and there was no signifi- (a) Summer

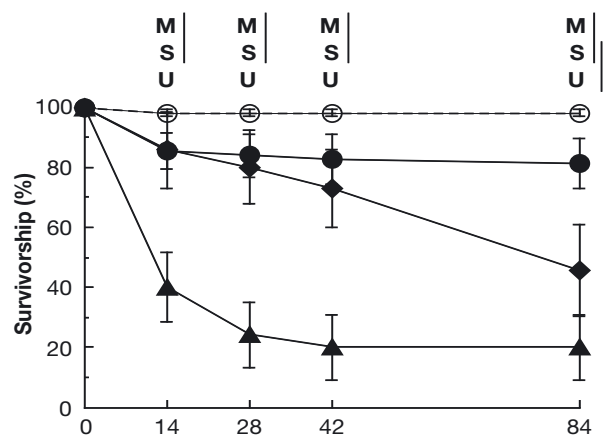

(b) Winter

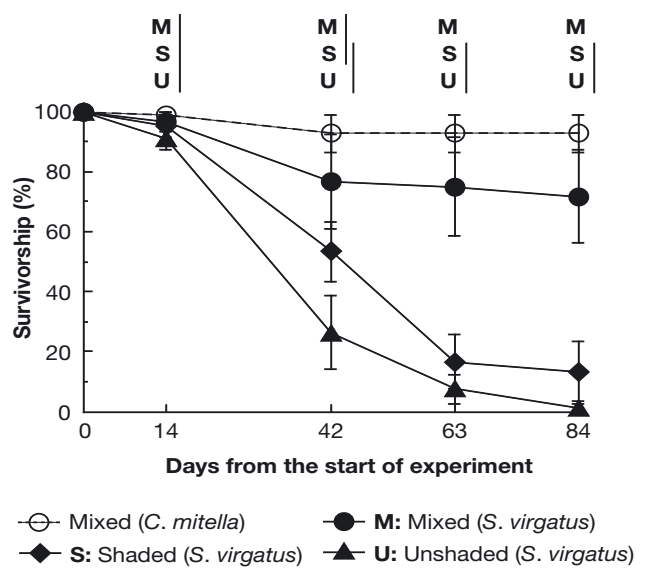

Fig. 3. Capitulum mitella and Septifer virgatus. Survivorship of C. mitella (dotted line) and $S$. virgatus (solid line) in transplant experiments in (a) summer and (b) winter. Values are untransformed means $\pm 1 \mathrm{SE}$. Vertical bars represent no significant difference (Scheffé's test: $\mathrm{p}>0.05$ ) in the survivorship of $S$. virgatus between any pair of groups concerned 
Table 2. Septifer virgatus. Results of 2-factor, repeated-measures ANOVA on the survivorship in the transplant experiment. Data were arcsine (square root) transformed before analysis. Denominator MS for the $F$ ratios: $b=$ Subject (group) error, $\mathrm{c}=$ Time $\times$ Subject (group) error

\begin{tabular}{|lrrrrr|}
\hline Source of variation & df & MS & $F$ & MS & p \\
\hline (a) Summer & & & & & \\
Treatment & 2 & 13227.03 & 9.07 & $\mathrm{~b}$ & 0.002 \\
Subject (group) error & 18 & 1457.65 & & & \\
Time & 4 & 6805.02 & 38.57 & $\mathrm{C}$ & $<0.001$ \\
Time $\times$ Treatment & 8 & 1219.56 & 6.91 & $\mathrm{C}$ & $<0.001$ \\
Time $\times$ Subject (group) error & 72 & 176.44 & & & \\
Total & 104 & & & & \\
& & & & & \\
(b) Winter & & & & & \\
Treatment & 2 & 11203.47 & 12.14 & $\mathrm{~b}$ & $<0.001$ \\
Subject (group) error & 17 & 922.84 & & & \\
Time & 4 & 16237.42 & 78.06 & $\mathrm{C}$ & $<0.001$ \\
Time $\times$ Treatment & 8 & 1726.87 & 8.30 & $\mathrm{C}$ & $<0.001$ \\
Time $\times$ Subject (group) error & 68 & 208.02 & & & \\
Total & 99 & & & & \\
\hline
\end{tabular}

\section{Thermal conditions}

Overall, thermal conditions were more severe (e.g. high temperature and low humidity) in the unshaded treatment than in the mixed and shaded treatments (Figs. $5 \& 6$ ). The mixed and shaded treatments showed similar habitat-ameliorating effects in terms of reducing thermal stress under almost all situations. In winter, however, those differences among treatments were negligible.

Shell surface temperature was significantly higher in the unshaded treatment than in the mixed and shaded treatments in summer (ANOVA: $1 \mathrm{~h}$, $F_{2,12}=138.69, \mathrm{p}<0.0001 ; 3 \mathrm{~h}, F_{2,16}=$ were consistent with the results of the removal experiment in which a higher survivorship of Septifer virgatus was recorded under the mixed situation with Capitulum mitella than in the single situation. Even in winter, however, the positive effect (of similar magnitude to summer) of $C$. mitella on $S$. virgatus was detected.

\section{Growth and shell wear}

Mussel growth was also positively affected by the presence of goose barnacles in the transplant experiment (Fig. 4a). The growth rate varied with treatments, but not with seasons nor with treatment $\times$ season interaction (Table 3). Only individuals in the mixed treatment showed positive growth in both seasons, while the shaded and unshaded treatment growth was negative, due probably to the faster rate of shell wear caused by wave action. Growth in the shaded treatment was negligibly negative in summer, while in winter the extent of negative growth was over 5 times larger than in summer. The growth rate of mussels in the unshaded treatment was the lowest, and similar in 2 seasons.

Almost all mussels that died during the experimental period had evidence of wear on their shells (Fig. 4b). The extent of shell wear in dead Septifer virgatus varied with treatments and seasons, with no treatment $x$ season interaction (Table 4), with individuals in the mixed treatment showing the least shell wear. Shell wear in all 3 treatments was more pronounced in winter than in summer.
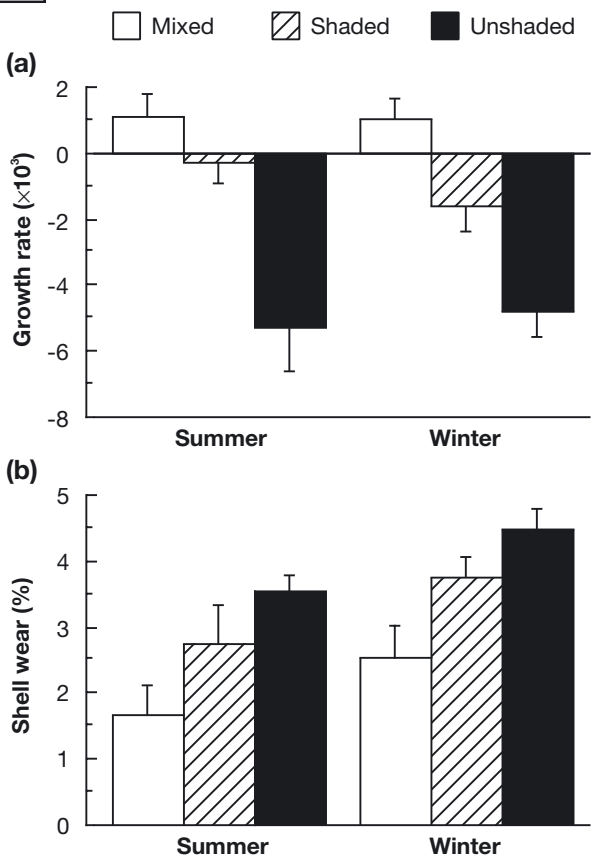

Fig. 4. Septifer virgatus. (a) Growth rate (relative size increase per day) and (b) shell wear (percentage) in dead $S$. virgatus in transplant experiments. Means $\pm 1 \mathrm{SE}$ (vertical bars) are shown

Table 3. Septifer virgatus. Results of 2-factor ANOVA on the growth rate in the transplant experiment

\begin{tabular}{|lrcrr|}
\hline Source of variation & df & MS & \multicolumn{1}{c|}{$F$} & \multicolumn{1}{c|}{$p$} \\
\hline Treatment & 2 & $1.00 \times 10^{-3}$ & 22.95 & $<0.001$ \\
Season & 1 & $4.19 \times 10^{-6}$ & 0.18 & 0.671 \\
Treatment $\times$ Season & 2 & $1.31 \times 10^{-5}$ & 0.57 & 0.569 \\
Residual & 228 & $2.32 \times 10^{-5}$ & & \\
Total & 233 & & & \\
\hline
\end{tabular}


Table 4. Septifer virgatus. Results of 2-factor ANOVA on shell wear in dead $S$. virgatus in the transplant experiment

\begin{tabular}{|lrrrr|}
\hline Source of variation & df & MS & $F$ & \multicolumn{1}{c|}{ p } \\
\hline Treatment & 2 & 33.47 & 7.40 & $<0.001$ \\
Season & 1 & 23.32 & 5.16 & 0.024 \\
Treatment $\times$ Season & 2 & 0.27 & 0.01 & 0.994 \\
Residual & 171 & 4.52 & & \\
Total & 176 & & & \\
\hline
\end{tabular}

14.39, $\mathrm{p}<0.001 ;$ Fig. 5). The highest temperature was $38.6^{\circ} \mathrm{C}$, recorded in the unshaded treatment after $3 \mathrm{~h}$ of exposure. In winter, shell surface temperature was low in all treatments and differences among treatments were either negligible or very small. The highest temperature was $11.0^{\circ} \mathrm{C}$ in the mixed treatment after $1 \mathrm{~h}$ of exposure.

The goose barnacle and the artificial shade could modify interstitial temperature within the transplanted patches (Fig. 6a). Interstitial temperature was similar among treatments at $1 \mathrm{~h}$ after low tide exposure in summer, while temperature in the unshaded treatment only increased from 1 to $3 \mathrm{~h}$ of exposure, and became significantly higher than in the mixed and shaded treatments (ANOVA: $F_{2,17}=8.77, \mathrm{p}=0.002$ ). In contrast, the mixed and the shaded treatments were stable and remained at similar temperatures irrespective of time of exposure. The highest temperature was $39.5^{\circ} \mathrm{C}$ recorded after $3 \mathrm{~h}$ of exposure in the unshaded treatment. In winter, interstitial temperatures were very low, with no significant difference among treatments and very small variation from 1 to $3 \mathrm{~h}$ of exposure $\left(\sim 1.5^{\circ} \mathrm{C}\right)$. The highest temperature was $8.9^{\circ} \mathrm{C}$ in the unshaded treatment after $1 \mathrm{~h}$ of exposure.

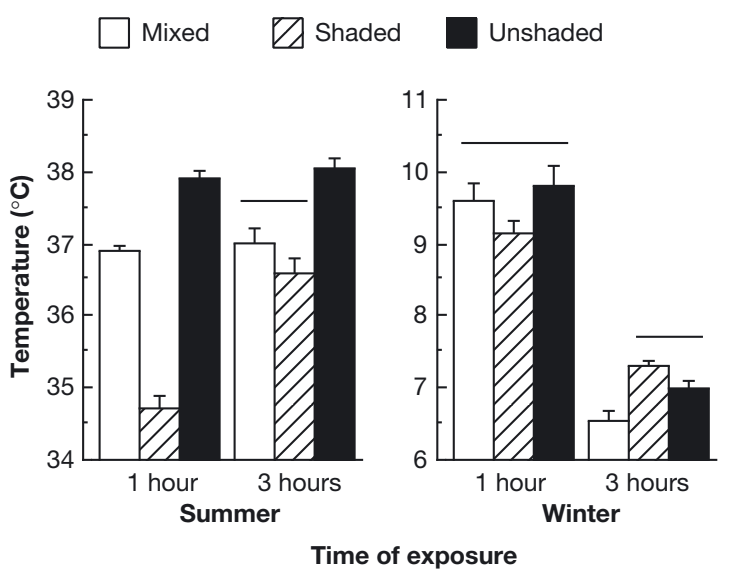

Fig. 5. Septifer virgatus. Shell surface temperature in transplant experiments after 1 and $3 \mathrm{~h}$ of low-tide exposure. Values are means $\pm 1 \mathrm{SE}$. Horizontal bars represent no significant difference (Scheffé's test: $p>0.05$ ) in temperature between any pair
The trends in interstitial humidity are shown in Fig. 6b. The significant difference among treatments was observed in summer, particularly at $3 \mathrm{~h}$ after low tide exposure (ANOVA: $F_{2,13}=3.84, \mathrm{p}=0.049$ ). Humidity in the unshaded treatment decreased by $7 \%$ from 1 to $3 \mathrm{~h}$ of exposure, and tended to be lower than in other treatments (though differences did not become statistically significant by Scheffé's multiple comparisons test). Although humidity in the mixed and the shaded treatments also showed a decrease with increasing exposure time, the ranges $(\sim 5 \%)$ were smaller than in the unshaded treatment $(\sim 7 \%)$. The lowest humidity was $36.1 \%$ in the unshaded treatment after $3 \mathrm{~h}$ of exposure. In winter, humidity was very high in all treat-
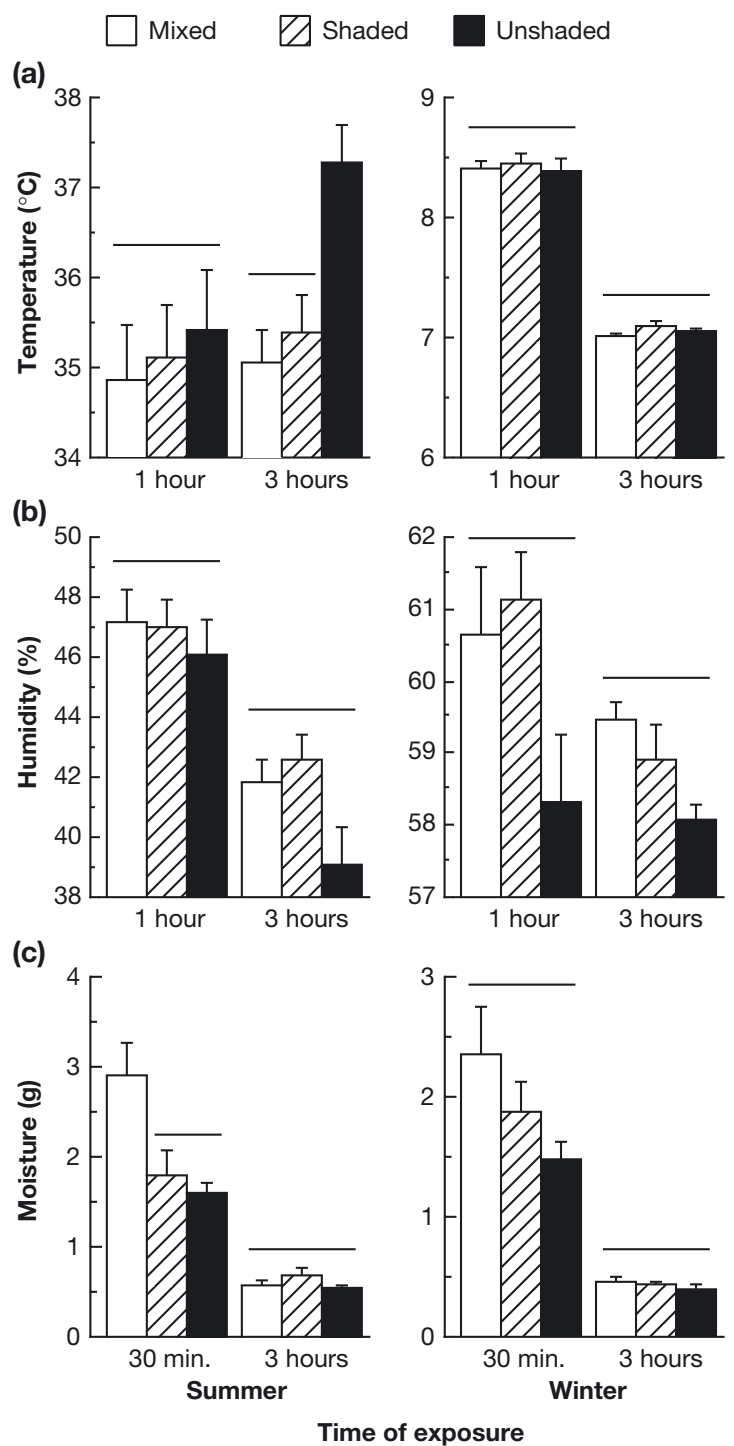

Fig. 6. (a) Interstitial temperature, (b) humidity and (c) the amount of water in transplant experiments after $1 \mathrm{~h}$ or $30 \mathrm{~min}$ and $3 \mathrm{~h}$ of low-tide exposure. Values are means $\pm 1 \mathrm{SE}$. Horizontal bars represent no significant difference (Scheffé's test: $\mathrm{p}>0.05)$ 
ments, and the magnitude of its decrease from 1 to $3 \mathrm{~h}$ of exposure was very small $(<3 \%)$. The lowest humidity was $56.3 \%$ in the unshaded treatment after $3 \mathrm{~h}$ of exposure; still a high value compared with summer.

Goose barnacles also contributed to increased water retention in an experimental patch, especially immediately after low-tide exposure (Fig. 6c). The amount of water was larger in the mixed treatment than in other treatments after $30 \mathrm{~min}$ of exposure, but the difference was significant only in summer (ANOVA: summer, $F_{2,15}=6.29, \mathrm{p}=0.010$; winter, $F_{2,13}=2.20, \mathrm{p}=0.15$ ). However, from $30 \mathrm{~min}$ to $3 \mathrm{~h}$ of exposure, the amount of water in all treatments declined to similar levels in both seasons, indicating that evaporative water loss is higher in the mixed treatment than in other treatments. In this case, different patterns were observed between the mixed and shaded treatments.

\section{DISCUSSION}

\section{Coexistence in similar-sized sessile organisms}

Body size differences are considered to facilitate species coexistence in some assemblages (Hutchinson 1959, Strong et al. 1979, Tokeshi 1999). Conversely, organisms with closely similar body sizes are more likely to compete for resources. In particular, interference competition for space is widespread among sessile organisms (Connell 1961, Paine 1984, Williamson 1990, Tokeshi \& Romero 1995). The present study has demonstrated that 2 sessile organisms, the goose barnacle Capitulum mitella and the mussel Septifer virgatus, can coexist in the upper intertidal, despite having similar body sizes and similar modes of resource utilization (space and food; in particular, habitable space on microhabitat scales is limited in the upper intertidal).

A number of studies demonstrated intraspecific facilitation involving individuals of similar size ranges (Ottaway 1979, Taylor \& Littler 1982, Bertness \& Groshloz 1985, Bertness 1989, Pineda \& Escofet 1989, Peterson \& Black 1993). In contrast, studies showing interspecific facilitation in organisms of similar sizes are very rare, particularly in animals (Bertness \& Yeh 1994, Lively \& Raimondi 1987, Hodge \& Arthur 1997). In the case of salt marsh plants living under hypersaline conditions, interspecific facilitation between seedlings occurred when salt tolerant species reduced substrate salinity, which in turn allowed salt intolerant but competitively superior species to survive (Bertness \& Yeh 1994). As these species grew, the tolerance of the competitively superior individual to high salinity increased with habitat amelioration by neighbouring subordinate species, which led to a shift in the nature of interspecific interactions from positive to negative. Lively \& Raimondi (1987) also demonstrated transient facilitation between acorn barnacles and mussels, in which the former facilitated the latter's settlement and juvenile survival, but interference competition for space ensued as the latter grew up. In contrast, the present study suggests that the survival of adult Septifer virgatus depended on the presence of Capitulum mitella and the benefit of association exceeded the magnitude of negative effects from interspecific interference competition. If $S$. virgatus with a potentially faster growth rate (15 $\mathrm{mm} \mathrm{yr}^{-1}$ in shell length in Hong Kong: Morton 1995) outcompeted C. mitella that had a slow growth rate $\left(2 \mathrm{~mm} \mathrm{yr}^{-1}\right.$ in rostral-carinal length: Nakamura \& Tanaka 1995) and/or increased its abundance vastly within mixed patches, $S$. virgatus would have become susceptible to harsh environmental conditions and suffered from a higher mortality. In conjunction with this, the morphological flexibility of $C$. mitella (a firm but flexible or even mobile peduncle of goose barnacles, Burnett 1987, Barnes 1996, Kugele \& Yule 2000) that could buffer interference competition seems to enhance the stable coexistence of the 2 species. On the other hand, the relative importance of the negative effects of $S$. virgatus on $C$. mitella may increase with decreasing environmental harshness (Bertness \& Callaway 1994, Brooker \& Callaghan 1998, Bertness et al. 1999, Bruno et al. 2003). Actually, competitively superior $S$. virgatus was dominant on vertical rock surfaces and overhangs where environmental conditions (both thermal and physical stresses) were relatively benign. In Paine's (1974) study, relatively benign thermal conditions on the North American coast may have led to the competitive exclusion of the goose barnacle Pollicipes polymerus by the mussel Mytilus californianus.

\section{Amelioration of multiple stresses}

While the majority of past studies dealt with a single stress factor and its variation (Stachowicz 2001), our study revealed that coexistence may be affected by 2 different stress factors at different times of year.

The importance of ameliorating thermal stress was particularly evident in summer, as demonstrated by the higher survivorship (Fig. 3a) and growth (Fig. 4a) of Septifer virgatus within the mixed and the shaded treatments. As the time of low tide exposure was longer, the habitat-ameliorating effect of Capitulum mitella became more evident: lower interstitial temperature and higher interstitial humidity (Fig. 6a,b) within the mixed patches than the unshaded patches after $3 \mathrm{~h}$ of low tide exposure. The higher survivorship of $S$. virgatus under the mixed conditions in summer, in both the field observation (Fig. 1) and the removal 
experiment (Fig. 2b), confirms this positive effect of C. mitella in mitigating thermal stress. Thermal conditions are closely linked to mussel body temperature and desiccation, which can affect mussel survivorship significantly (Helmuth 1998). Liu \& Morton (1994) showed that $S$. virgatus did not survive a $6 \mathrm{~h}$ exposure to air temperature of $34^{\circ} \mathrm{C}$ and rock surface temperature of $40^{\circ} \mathrm{C}$. In our case, interstitial air temperature constantly exceeded $35^{\circ} \mathrm{C}$ only in the unshaded treatment (Fig. 6a), and the maximum temperature was $39.5^{\circ} \mathrm{C}$, recorded in the unshaded treatment at midday low tide in summer. In addition, time of exposure at spring tide was longer than $5 \mathrm{~h}$ in the upper intertidal in our study site. Therefore, the thermal condition in the unshaded treatment in summer was sufficiently severe to cause significant mortality in $S$. virgatus.

In winter when thermal stress was weak (Figs. $5 \& 6$ ) but physical stress by wave action was severe (Fig. 4b), the amelioration of physical stress was apparently more important. It is notable that during the first $14 \mathrm{~d}$ of the transplant experiment in winter, Septifer virgatus in all treatments showed a high survivorship in contrast to the summer season (Fig. 3b), probably due to calm sea and mild thermal conditions (Figs. 5 \& 6). However, S. virgatus survivorship in the shaded and unshaded patches, but not in the mixed patches, rapidly declined from Day 14 onwards (Fig. 3b) when rough sea conditions prevailed. Thus, the presence of Capitulum mitella apparently mitigated the negative effects of wave-caused physical disturbance on mussels.

\section{Structural characteristics of Capitulum mitella aggregations}

The fact that Capitulum mitella has a higher tolerance of thermal stress than Septifer virgatus is demonstrated by its high survivorship under both natural and experimental conditions in summer (Figs. 1a, 2 \& 3a) and by its wide range of distribution towards the upper elevation (Mori et al. 1985a,b, Tanaka et al. 1985). Further, C. mitella is also more tolerant of strong hydrodynamic forces than $S$. virgatus. While a lift force acting in a perpendicular direction is the most significant dislodgement agent for mussels (Denny 1987), it has little effect on a goose barnacle that is directly attached to the rock surface by solid cement, whereby no significant difference in hydrostatic pressure occurs between the upper and the lower side of its body (Denny 1995). In addition, the flexible peduncle of a goose barnacle (Burnett 1987, Barnes 1996) can buffer drag forces that act in the direction of flow more efficiently, like in algae (Gaylord et al. 1994), compared with mussels with inflexible shells. Consequently, C. mitella is less likely to be dislodged by hydrodynamic forces than $S$. virgatus. Actually, C. mitella survivorship was constantly higher than $S$. virgatus under all situations in winter when physical stress was severe (Figs. $1 \mathrm{~b} \& 3 \mathrm{~b}$ ).

Living in either conspecific or heterospecific groups can reduce an individual's risk of being damaged and killed, because the presence of neighbours directly or indirectly buffers environmental extremes (e.g. acorn barnacles: Bertness 1989; mussels: Bell \& Gosline 1997, Helmuth 1998; sea anemone: Ottaway 1979, Pineda \& Escofet 1989; algae: Dayton 1975, Hay 1981, Bertness et al. 1999; marsh grasses: Leonard \& Luther 1995, Bruno 2000; seagrasses: Orth et al. 1984, Irlandi \& Peterson 1991; large polychaete tubes: Woodin 1978). In the present case, an aggregation of Capitulum mitella shielded the rock surface from irradiation so that it remained cooler than areas without C. mitella. Moreover, the magnitude of evaporative cooling, which is considered to be effective in lowering mussel equilibrium body temperature (Helmuth 1998), must be greater in $C$. mitella aggregations, as evidenced by a large amount of water loss from mixed patches compared with other patches, particularly in summer (Fig. 6c). In addition, C. mitella aggregation may modify hydrodynamic forces caused by pounding wave action due to $C$. mitella's 3-dimensional and flexible structure. Consequently, Septifer virgatus can benefit greatly from being in a mixed patch, where both thermal conditions and hydrodynamic forces are ameliorated. The artificial shade could closely mimic the habitat-modifying effects of C. mitella in terms of reducing thermal stress, but failed to reduce hydrodynamic forces. Thus, the survivorship of mussels was substantially low in the shaded treatment and there was no difference between the shaded and the unshaded treatments in winter (Fig. 3b). Our experimental design used in the present study, however, could not separate the relative contributions of these 2 different habitat-modifying functions caused by goose barnacles precisely.

\section{CONCLUSION}

The results of this study give credence to a hypothesis that coexistence in the 2 species, the goose barnacle Capitulum mitella and mussel Septifer virgatus, was a consequence of seasonally variable modes of facilitation. C. mitella affected the survivorship and growth of $S$. virgatus positively through amelioration of thermal stress in summer and of physical disturbance in winter.

Thus, the present study has demonstrated that facilitation can occur even in potentially competing organisms with similar body sizes and feeding modes. It may 
therefore be suggested that coexistence promoted by facilitation is not uncommon in many systems, particularly under harsh environmental conditions. Moreover, our study has indicated temporally variable modes of facilitation even in the same relationship. Our ongoing experiments using transparent physical barriers and facilitation 'mimics' (Bruno et al. 2003) are expected to further unravel the complex mechanisms underlying this temporally varying facilitation and the compound nature of species interactions. More investigation, coupled with a mechanistic approach, will be needed for a broader understanding of community organisation in different systems.

Acknowledgements. We would like to thank Messrs. S. Nojima, K. Mori, T. Sameshima and K. Tanaka for logistical support, M. Azuma for help with field work and other members of the Amakusa Marine Biological Laboratory for constant encouragement and advice throughout this study. This research was partly supported by the 21st Century COE programme from the Ministry of Education, Culture, Sports and Technology, the Fujiwara Natural History Foundation (a research grant to T.K.) and the Japan Society for the Promotion of Science ('Grant-In-Aid' nos. 14255013 and 14340246 to M.T.).

\section{LITERATURE CITED}

Abrams PA, Menge BA, Mittelbach GG, Spiller DA, Yodzis P (1996) The role of indirect effects in food webs. In: Polis GA, Winemiller KO (eds) Food webs: integration of patterns and dynamics. Chapman \& Hall, New York, p 371-395

Barnes M (1996) Pedunculate cirripedes of the genus Pollicipes. Oceanogr Mar Biol Annu Rev 34:303-394

Bell EC, Gosline JM (1997) Strategies for life in flow: tenacity, morphometry, and probability of dislodgment of two Mytilus species. Mar Ecol Prog Ser 159:197-208

Bertness MD (1989) Intraspecific competition and facilitation in a northern acorn barnacle population. Ecology 70:257-268

Bertness MD, Callaway RM (1994) Positive interactions in communities. Trends Ecol Evol 9:191-193

Bertness MD, Grosholz E (1985) Population dynamics of the ribbed mussel, Geukensia demissa: the costs and benefits of an aggregated distribution. Oecologia 67:192-204

Bertness MD, Yeh SM (1994) Cooperative and competitive interactions in the recruitment of marsh elders. Ecology 75:2416-2429

Bertness MD, Leonard GH, Levine JM, Schmidt PR, Ingraham AO (1999) Testing the relative contribution of positive and negative interactions in rocky intertidal communities. Ecology 80:2711-2726

Brooker RW, Callaghan TV (1998) The balance between positive and negative plant interactions and its relationship to environmental gradients: a model. Oikos 81:196-207

Bruno JF (2000) Facilitation of cobble beach plant communities through habitat modification by Spartina alterniflora. Ecology 81:1179-1192

Bruno JF, Stachowicz JJ, Bertness MD (2003) Inclusion of facilitation into ecological theory. Trends Ecol Evol 18: $119-125$

Burnett BR (1987) The cirripede circulatory system and its evolution. In: Southward AJ (ed) Crustacean issues. 5. Barnacle biology. AA Balkema, Rotterdam, p 175-190
Callaway RM (1992) Effect of shrubs on recruitment of Quercus douglasii and Quercus lobata in California. Ecology 73:2118-2128

Callaway RM (1995) Positive interactions among plants. Bot Rev 61:306-349

Callaway RM, Walker LR (1997) Competition and facilitation: a synthetic approach to interactions in plant communities. Ecology 78:1958-1965

Callaway RM, Nadkarni NM, Mahall BE (1991) Facilitation and interference of Quercus douglasii on understory productivity in central California. Ecology 72:1484-1499

Callaway RM, Brooker RW, Choler P, Kikvidze Z and 9 others (2002) Positive interactions among alpine plants increase with stress. Nature 417:844-848

Chapin FS III, Walker LR, Fastie CL, Sharman LC (1994) Mechanisms of primary succession following deglaciation at Glacier Bay, Alaska. Ecol Monogr 64:149-175

Connell JH (1961) The influence of interspecific competition and other factors on the distribution of the barnacle Chthamalus stellatus. Ecology 42:710-723

Connell JH (1978) Diversity in tropical rain forests and coral reefs. Science 199:1302-1310

Connell JH, Slatyer RO (1977) Mechanisms of succession in natural communities and their role in community stability and organization. Am Nat 111:1119-1144

Dayton PK (1975) Experimental evaluation of ecological dominance in a rocky intertidal algal community. Ecol Monogr 45:137-159

Denny MW (1987) Lift as a mechanism of patch initiation in mussel beds. J Exp Mar Biol Ecol 113:231-245

Denny MW (1995) Predicting physical disturbance: mechanistic approaches to the study of survivorship on wave-swept shores. Ecol Monogr 65:371-418

Gaylord B, Blanchette CA, Denny MW (1994) Mechanical consequences of size in wave-swept algae. Ecol Monogr 64:287-313

Hawkins SJ (1981) The influence of season and barnacles on the algal colonization of Patella vulgate exclusion areas. J Mar Biol Assoc UK 61:739-750

Hay ME (1981) The functional morphology of turf-forming seaweeds: persistence in stressful marine habitats. Ecology 62:739-750

Heck KL Jr, Orth RJ (1980) Seagrass habitats: the roles of habitat complexity, competition and predation in structuring associated fish and motile macroinvertebrate assemblages. In: Kennedy VS (ed) Estuarine perspectives. Academic Press, New York, p 449-464

Helmuth BST (1998) Intertidal mussel microclimates: predicting the body temperature of a sessile invertebrate. Ecol Monogr 68:51-74

Hjältén J, Danell K, Lundberg P (1993) Herbivore avoidance by association: vole and hare utilization of woody plants. Oikos 68:125-131

Hodge S, Arthur W (1997) Asymmetric interactions between species of seaweed fly. J Anim Ecol 66:743-754

Hutchinson GE (1959) Homage to Santa Rosalia, or why are there so many kinds of animals? Am Nat 93:145-159

Irlandi EA, Peterson CH (1991) Modification of animal habitats by large plants: mechanisms by which seagrasses influence clam growth. Oecologia 87:307-318

Kugele M, Yule AB (2000) Active relocation in lepadomorph barnacles. J Mar Biol Assoc UK 80:103-111

Leonard GH (1999) Positive and negative effects of intertidal algal canopies on recruitment and survival of barnacles. Mar Ecol Prog Ser 178:241-249

Leonard LA, Luther ME (1995) Flow hydrodynamics in tidal marsh canopies. Limnol Oceanogr 40:1474-1484 
Liu JH, Morton B (1994) The temperature tolerances of Tetraclita squamosa (Crustacea: Cirripedia) and Septifer virgatus (Bivalvia: Mytilidae) on a sub-tropical rocky shore in Hong Kong. J Zool 234:325-339

Lively CM, Raimondi PT (1987) Desiccation, predation, and mussel-barnacle interactions in the northern Gulf of California. Oecologia 74:304-309

Menge BA (1978a) Predation intensity in a rocky intertidal community: relation between predator foraging activity and environmental harshness. Oecologia 34:1-16

Menge BA (1978b) Predation intensity in a rocky intertidal community: effect of an algal canopy, wave action and desiccation on predator feeding rates. Oecologia 34:17-35

Menge BA (1995) Indirect effects in marine rocky intertidal interaction webs: patterns and importance. Ecol Monogr 65:21-74

Miller TE (1994) Direct and indirect species interactions in an early old-field plant community. Am Nat 143:1007-1025

Mori K, Nishihama S, Tanaka M (1985a) Community structure of a rocky shore in Tsuji-shima Island, Amakusa. III. The analysis of relationships between distribution of organisms and micro-topographical conditions using small quadrat. Publ Amakusa Mar Biol Lab 8:43-63

Mori K, Tanaka M, Nishihama S (1985b) Community structure of a rocky shore in Tsuji-shima Island, Amakusa. II. Vertical distribution of dominant species and its zonation pattern. Publ Amakusa Mar Biol Lab 8:27-41

Morton B (1995) The population dynamics and reproductive cycle of Septifer virgatus (Bivalvia: Mytilidae) on an exposed rocky shore in Hong Kong. J Zool 235:485-500

Nakamura RKG, Tanaka M (1989) Clumps of the stalked barnacle Capitulum mitella as habitats for intertidal animals. Publ Amakusa Mar Biol Lab 10:65-77

Nakamura RKG, Tanaka M (1995) Effects of aggregation on growth and survival of the intertidal stalked barnacle, Capitulum mitella. Benthos Res 49:29-37

Navarrete SA, Castilla JC (1990) Barnacle walls as mediators of intertidal mussel recruitment: effects of patch size on the utilization of space. Mar Ecol Prog Ser 68:113-119

Nobel PS (1984) Extreme temperatures and thermal tolerances for seedling of desert succulents. Oecologia 62: 310-317

Orth RJ, Heck KL Jr, van Montfrans J (1984) Fauna communities in seagrass beds: a review of the influence of plant structure and prey characteristics on predator-prey relationships. Estuaries 7:339-350

Ottaway JR (1979) Population ecology of the intertidal anemone Actinia tenebrosa. III. dynamics and environmental factors. Aust J Mar Freshw Res 30:41-62

Paine RT (1966) Food web complexity and species diversity. Am Nat 100:65-75

Paine RT (1974) Intertidal community structure: experimental studies on the relationship between a dominant competitor and its principal predator. Oecologia 15:93-120

Paine RT (1984) Ecological determinism in the competition for space. Ecology 65:1339-1348

Peterson CH, Black R (1993) Experimental tests of the advantages and disadvantages of high density for two coexisting cockles in a Southern Ocean lagoon. J Anim Ecol 62: 614-633

Pineda J, Escofet A (1989) Selective effects of disturbance on populations of sea anemones from northern Baja California, Mexico. Mar Ecol Prog Ser 55:55-62

Schoener TW (1974) Resource partitioning in ecological

Editorial responsibility: Otto Kinne (Editor),

Oldendorf/Luhe, Germany communities. Science 185:27-39

Schoener TW (1994) On the relative importance of direct versus indirect effects in ecological communities. In: Kawanabe H, Cohen JE, Iwasaki K (eds) Mutualism and community organization: behavioural, theoretical, and food-web approaches. Oxford University Press, Oxford, p 365-411

Stachowicz JJ (2001) Mutualism, facilitation, and the structure of ecological communities. BioScience 51:235-246

Stoner AW, Lewis FG III (1985) The influence of quantitative and qualitative aspects of habitat complexity in tropical seagrass meadows. J Exp Mar Biol Ecol 94:19-40

Strauss SY (1991) Indirect effects in community ecology: their definition, study and importance. Trends Ecol Evol 6: 206-210

Strong DR, Szyska LA, Simberloff DS (1979) Tests of community-wide character displacement against null hypotheses. Evolution 33:897-913

Suchanek TH (1985) Mussels and their role in structuring rocky shore communities. In: Moore PG, Seed R (eds) The ecology of rocky coasts. Hodder \& Stoughton, London, p 70-96

Tanaka M, Mori K, Nojima S, Kikuchi T, Shibata T, Nishino T, Omori K (1985) Community structure of a rocky shore in Tsuji-shima Island, Amakusa. I. Horizontal and vertical distribution pattern of common animals. Publ Amakusa Mar Biol Lab 8:1-26

Taylor PR, Littler MM (1982) The roles of compensatory mortality, physical disturbance, and substrate retention in the development and organization of a sand-influenced, rocky-intertidal community. Ecology 63:135-146

Thompson RC, Wilson BJ, Tobin ML, Hill AS, Hawkins SJ (1996) Biologically generated habitat provision and diversity of rocky shore organisms at a hierarchy of spatial scales. J Exp Mar Biol Ecol 202:73-84

Tilman D (1982) Resource competition and community structure. Princeton University Press, Princeton, NJ

Tokeshi M (1999) Species coexistence: ecological and evolutionary perspectives. Blackwell Science, Oxford

Tokeshi M, Romero L (1995) Filling a gap: dynamics of space occupancy on a mussel-dominated subtropical rocky shore. Mar Ecol Prog Ser 119:167-176

Walker LR, Vitousek PM (1991) An invader alters germination and growth of a native dominant tree in Hawai'i. Ecology 72:1449-1455

Williams SL (1990) Experimental studies of Caribbean seagrass bed development. Ecol Monogr 60:449-469

Williamson GB (1990) Allelopathy, Koch's postulates, and the neck riddle. In: Grace JB, Tilman D (eds) Perspectives on plant competition. Academic Press, New York, p 143-162

Witman JD (1987) Subtidal coexistence: storms, grazing, mutualism, and the zonation of kelps and mussels. Ecol Monogr 57:167-187

Woodin SA (1978) Refuges, disturbance, and community structure: a marine soft-bottom example. Ecology 59: $274-284$

Wootton JT (1994a) Predicting direct and indirect effects: an integrated approach using experiments and path analysis. Ecology 75:151-165

Wootton JT (1994b) The nature and consequences of indirect effects in ecological communities. Annu Rev Ecol Syst 25: $443-466$

Zar JH (1996) Biostatistical analysis, 3rd edn. Prentice Hall, Upper Saddle River, NJ

Submitted: November 10, 2003; Accepted: January 27, 2004

Proofs received from author(s): March 24, 2004 